\title{
국제개발협력 분야별 민관협력 활성화 방안 ${ }^{11}$ \\ - 기후변화 분야 -
}

김 대 환 · 박 희 수 · 임 소 영 KOICA 기후변화대응반

\section{I. 서론}

2015년을 기한으로 하는 새천년개발목표(MDGs) 달성을 위해 공적개발원조(ODA) 재원 확대와 원 조효과성 제고에 대한 논의가 계속되고 있다. $\mathrm{OECD}$ 개발원조위원회(DAC)의 공여국들은 GNI 대 비 $0.7 \%$ 이상으로 $\mathrm{ODA}$ 재원을 확대해야 한다는 UN의 권고를 받고 있지만, 2007 년도 기준 $0.28 \%$ 에 그치는 수준이며, 2008년말 글로벌 경제위기의 여파로 인해 당분간 ODA 재원 확대는 쉽게 달 성되기는 어려울 것으로 보인다.

또한 최근 5년간 개도국으로 유입된 자금의 흐름을 살펴보면, $\mathrm{ODA}$ 는 2003년 55\%에서 2007년 $23 \%$ 로 그 비중이 절반 수준으로 감소한 반면, 민간자금의 흐름(Private Flow)은 2003년 37\%에서 2007 년 $74 \%$ 로 두 배로 증가한 사실을 확인할 수 있다(OECD, 2009). 이러한 경향을 볼 때, 개도 국에 대한 개발협력에 있어서 민간자금을 유인하고 공공자금을 보다 효율적으로 활용하고자 하는 민관협력(PPP)의 역할이 개발효과성(development effectiveness) 제고를 위해 더욱 중요해지고 있음을 알 수 있다.

민간부문의 역할은 기후변화 대응에 있어서도 더욱 강조되고 있다. 기후변화 대응방안은 크게 완화 와 적응으로 분류되는데, 완화는 기후변화의 원인이 되는 온실가스 배출량을 줄이거나 이미 배출된 온실가스를 회수하는 노력이며 적응은 진행 또는 예측되는 기후변화로 인한 피해에 대비하는 노력 이다. 개발도상국들은 이러한 기후변화의 부정적인 영향을 완화하고 적응해가는 과정에서 재정적, 기술적, 제도적 역량이 충분히 갖춰져 있지 않아 결국 선진국의 재정지원과 기술이전을 필요로 하 게 된다. 그러나 $\mathrm{ODA}$ 등 공공재원만으로는 이런 요구를 충당할 수 없으므로 민간부문의 참여가 필

1) 본 보고서는 『국제개발협력』2009년 2호에 수록된「기후변화 관련 최근 원조 현황과 논의 방향(1) - 물 분야」에 이은 기후변화 분석 보고서이며, 향후 보고될 신재생에너지 분야를 포함하여 시리즈로 진행되고 있습니다. 
수적인데, 여기서 민간부문은 주로 공공부문의 법제도, 보조금, 공동투자 등의 지원과 협력하여 기 후친화적인 기술의 개발 및 보급, 대규모 인프라시설을 위한 자금 투자 등의 형태로 참여한다.

본고에서는 기후변화 대응에 있어서 민관협력(PPP)의 필요성을 간략히 짚어보고, 기후변화 완화와 적응 각 분야에서 실제로 이루어지고 있는 특징적인 민관협력의 현황을 살펴보고자 한다.

\section{II. 기후변화 대응을 위한 민관협력의 필요성}

국제사회가 기후변화에 대응하는 데는 공공부문의 노력만으로는 달성될 수 없으며 민간의 자본과 기술 등을 유입하는 게 필수적이다. 이는 기후변화의 완화와 적응을 위해 요구되는 비용이 막대하 여 공공재원만으로는 이런 요구를 충족시키기 어렵기 때문이다. 그런데 민간기업의 입장에서는 기 후변화 관련 시장의 장기적인 지속가능성이 불확실한 상황에서, 단순히 사회적 책임의식만을 바탕 으로 단기적인 이윤추구를 무시한 채 장기적인 관점의 투자를 하기란 쉽지 않은 일이다. 그러므로 공공부문은 적합한 정책과 금융지원을 통해 민간자본을 유인해야 하는데, 이러한 과정에서 민간기 업의 투자 리스크를 줄이는 공공금융과 기후친화적인 기술개발을 장려하는 시장 인센티브 등을 반 영한 민관협력의 역할이 강조된다.

\section{1. 기후변화 대응을 위한 추가적인 재원}

산업화 이후 현재까지 배출된 온실가스는 대부분 고소득국가로부터 비롯된 것으로 개발도상국에서 발생한 온실가스는 전체의 25\%도 못 미치고 있다(Stern, 2006). 그럼에도 불구하고 기후변화로 인해 발생하는 부정적인 영향은 그 역사적 책임과는 무관하게도 개발도상국에서 집중적으로 나타 난다. 이는 많은 개발도상국들이 기후변화에 취약한 지리적 위치와 환경적 특성을 가지고 있기 때 문이기도 하지만, 보다 근본적으로 기후변화에 적절히 대응할 수 있는 제도적, 재정적 그리고 기술 적 역량이 부족하기 때문이다.

그래서 기후변화협약은 선진국들이 기존에 약속한 ODA 외에 '추가적인(new and additional)' 재 원으로 개도국에 기술이전을 제공해야 한다고 규정하고 있다. 여기서 추가적인 재원이란 선진국에 서 개도국으로 유입되는 공공자금의 흐름을 말하는 것이지만 그 기준선(baseline)을 제시하고 있지 는 않기 때문에 이를 해석하는 데 있어서 선진국과 개도국이 각기 다른 입장을 보이고 있다.

선진국들은 개도국의 기후변화 대응을 위한 지원금은 $\mathrm{ODA}$ 로 계상되어야 한다는 입장을 보이고 있 
다. 그 근거로는 기후변화가 개도국의 개발에 있어서 핵심적인 요소이기 때문에 공여국들의 개발협 력 활동에 통합되어야 한다는 점과, 개발협력사업과 기후변화대응사업을 구분하기가 어렵다는 점, 그리고 개발협력사업을 수행하는 원조기관들의 전문성과 경험을 활용할 수 있다는 점 등을 들고 있 다(Anna, 2008). 그러나 선진국들이 ODA 재원 확대에도 어려움을 겪고 있어 기후변화대응 지원 을 위한 추가재원 마련이라는 이중 부담을 줄이고자 하는 게 실제적인 이유라는 관측이 있다.

이에 반해 개도국들은 기후변화 문제에 있어서는 특별히 선진국들의 역사적 책임을 강조해오 고 있다. 즉, 개도국의 빈곤퇴치를 위한 선진국들의 지원은 ‘원조(aid)'라고 볼 수 있지만, 기후 변화대응을 위한 지원은 선진국들이 과거에 배출한 온실가스에 대해 역사적 책임을 지는 '보상 (compensation)'으로 이해해야 한다는 것이다. 실례로 중국은 모든 선진국들이 기존 ODA에 GDP 의 $0.5 \%$ 를 추가적으로 마련하는 목표를 제안했으며, 지난 8월에는 아프리카 10 개국 장관들이 12 월 코펜하겐 회의 전 아프리카 국가들의 기후변화대응 공동입장 마련을 위한 모임(8.24, 에티오피 아)에서 선진국에게 아프리카 국가들의 기후변화 대응을 위한 비용으로 연간 670 억 달러를 지원 요 청한 바 있다. ${ }^{2)}$ 따라서 선진국들은 개도국의 기후변화 대응을 위해 현 수준의 ODA 보다 가시적으 로 재원을 확대하는 노력이 불가피한 상황이다.

그러나 공공자금만으로는 기후변화 대응을 위해 요구되는 전체 재원규모를 충족시킬 수 없을 것으 로 보인다. UNFCCC에서는 2030년까지 전 세계적인 기후변화 완화를 위해 매년 최대 2,100 억 달 러를 필요하다고 발표하였으며, UNDP는 인간개발보고서에서 선진국들이 개도국의 기후변화 적 응을 위해 ODA 외에 추가적으로 2016년까지 최대 860억 달러를 지원해야 한다고 권고한 바 있다 (UNDP, 2007). 2007년 기준 전 세계 총 ODA 규모가 1,000억 달러임을 감안할 때 기후변화 대응 에 필요한 추가적인 비용은 막대한 수준임을 알 수 있다. 그러므로 기후변화 대응에 있어서의 민간 부문의 참여와 $\mathrm{PPP}$ 에 대한 더욱 큰 관심이 요구된다.

\section{2. 민간기업의 관점: UN 글로벌 컴팩트}

기후변화 대응에 있어서 자발적인 민간부문의 참여와 민관협력을 촉진하기 위해서는 민간기업의 관점을 이해하는 것이 중요하다. 민간기업은 기후변화 문제를 위기요인인 동시에 기회요인이라는 두 가지 측면에서 보고 있다. 청정개발체제 $(\mathrm{CDM})^{3)}$, 공동이행제도 $(\mathrm{JI})^{4)}$, 배출권 거래제 $(\mathrm{ET})$ 등 교

2) http://www.pointcarbon.com/news/1.1198671(2009.9.1)

3) 청정개발체제 (Clean Development Mechanism): 온실가스 감축의무가 있는 국가들 (부속서I)과 없는 국가들 (비부속서) 간에 이루어지는 것으로, 감축 비용이 싼 다른 국가에서 온실가스감축 사업을 수행하고 발생한 감축분 (Certified Emission Reduction, CER)을 자국의 감축실적으로 인정받는 제도

4) 공동이행제도 (Joint Implementation): 온실가스 감축의무가 있는 부속서 국가들 간에 이루어지는 것으로, 감축 비용이 싼 다른 국가에서 온실가스를 줄이고 발생한 감축분 (Emission Reduction Unit, ERU)은 자국의 감축실적으로 인정받는 제도 
토 메커니즘 하에서 새롭게 형성된 탄소시장은 기업들에게 새로운 비즈니스 기회가 되고 있지만, 기후변화는 동시에 인류사회의 지속가능한 발전을 저해하는 위협요인으로서 기업의 사회적 책임 (CSR)을 요구하고 있다.

이러한 관점은 유엔 글로벌 컴팩트의 활동에서 대표적으로 찾아볼 수 있다. UN 글로벌 컴팩트 는 2000년 UN의 주도하에 인권, 노동, 환경, 반부패 등의 분야에서 기업의 사회적 책임을 강조하 기 위해 생겨난 자발적인 민간기업 참여 사업이다. 2007년 UN 사무총장이 글로벌 컴팩트를 통해 ‘Caring for Climate’라는 비즈니스 주도의 이니셔티브를 발표하면서 기후변화 대응 및 저탄소 경 제로의 전환을 위한 민간부문의 역할 측면에서 주목을 받고 있다. 유엔 글로벌 콤팩트에 참여한 기 업들은 기후변화로 인한 위험이 인권, 노동, 그리고 훌륭한 거버넌스와 같은 기존의 사회적 책임 운 동과 밀접하게 연관되어 있음을 인식하면서 궁극적으로 경제개발과 사회적 진보를 향한 모든 목적 자체를 위협하는 요인으로 받아들이고 있다. 예를 들어, 탄소배출에 적정가격을 책정시키고자 하는 국제 기후협약은 개방과 경쟁을 기반으로 한 국제 탄소시장을 지속시키는데 기여할 것이다. 하지만 만일 이 협약이 실패할 경우에는 무역장벽이나 차별적인 탄소과세가 등장하여 많은 기업들과 투자 자들이 의지하고 있는 국제경제의 기반 자체를 뒤흔들어 놓을 수도 있다.

그러므로 민간부문이 보다 활발한 투자를 할 수 있기 위해서는 우선 탄소시장체제가 신뢰할만하고 견고하게 자리 잡아야 할 것이다. 국제 탄소시장체제의 지속가능성은 이해관계자들의 공조 속에 유 지될 수 있으며, 특히 정부, 국제기구 및 기업 간의 협력체계는 이를 결정하는 중요한 요인이 될 것 이다.

\section{3. 공공부문의 역할: 공공금융과 정책}

UNFCCC에 따르면 전 세계 민간투자의 1.1 1.7\%로 2030년까지의 기후변화 완화를 위한 필요재 원을 충족시킬 수 있다고 한다. 따라서 민간자본이 적절히 유입될 수 있는 환경만 조성된다면 기후 변화대응을 위한 재원 확보도 전혀 불가능한 애기라고 볼 수는 없다. 때문에 공공금융이 적합한 정 책과 조합하여 저탄소 녹색경제를 구축할 수 있도록 민간투자를 촉진하고 지레작용(leverage)할 수 있도록 하는 역할을 수행해야 한다.

공공금융이 민간투자를 유인하는데 있어서는 '위험(risk)'과 '환급(return)'이라는 두 가지 결정 적 요소가 강조된다. 위험은 전통적인 재정수단을 통해서 감소시킬 수 있는데, 신기술 개발을 실패 한 기업들에 대한 지불보증 또는 보험 상품 등이 그 예라고 할 수 있다. 또한 환급은 사업비를 보조 하는 차관이나 무상지원을 통해 이루어질 수 있다. 그리고 이러한 상품들이 정부 또는 국제적인 재 
정기구들의 포트폴리오를 형성하면서 개도국에 대한 온실가스 감축기술 사업에 현지은행의 참여와 민간투자를 자극하는 기능을 하게 된다. 그러나 보조금이나 위험 완화 장치들은 시장을 왜곡하는 문제를 야기할 수 있어 정규의 프로젝트 금융활동과 반드시 연계되어야 한다. 대표적으로 세계은행 에서는 61 억불 상당의 기후투자기금 $(\mathrm{CIF})$ 을 조성하여 전략적으로 기후를 보호하는 방식의 대부절 차를 강화하고 있다. 즉 화석연료 기반의 발전소에 대한 지원을 줄이고 대신에 재생에너지의 사용 을 증진하는 등의 방식을 적용하고 있다.

또한 공공부문은 민간투자를 자극하기 위해 적절한 시장인센티브를 제공해야 한다. 온실가스를 배 출하는 활동들은 경제적인 외형만을 갖춘 경우가 많은데 여기에 적절한 사회적 비용도 부담시켜야 한다. 만일 온실가스를 배출하는 가격이 낮을 경우 청정에너지가 갖는 이점은 줄어들게 되기 때문 이다. 유럽연합의 탄소배출권거래제(EU ETS)가 어려움을 겪고 있는 원인도 여기에 있다. 현재까 지는 예측가능하고 적합하게 설정된, 전 세계적으로 통용되는 온실가스 배출가격은 마련되지 않은 상태이다. 오히려 화석연료에 보조금을 제공하는 사례들도 많이 있는데 이는 심각한 시장왜곡과 더 불어 그릇된 인센티브를 조장하고 있다. 그러므로 개도국 정부를 포함한 공공부문은 장기간 지속될 수 있고, 민간 투자자들에게 명확하게 이해될 수 있으며, 법적 기반을 갖춘 정책을 수립해야 한다.

\section{III. 완화 분야의 민관협력 현황}

\section{1. 신재생에너지 분야 민관협력}

세계는 산업화, 도시화, 자동화에 따른 에너지 수요의 증가 및 기후변화의 원인인 탄소배출의 감소 라는 두 가지의 상반된 요구를 모두 만족해야 하는 어려움에 봉착해 있다. 이와 같은 어려움을 해결 하기 위한 방안으로서 화석연료를 대체할 신재생에너지의 개발 및 보급을 위한 노력이 정부와 민간 부문 모두에서 활발히 진행 중이다.

신재생에너지 분야에서는 주로 정부가 신재생에너지의 개발 및 보급을 활성화하는 제도를 마련하 고 보조금을 지원하면, 민간은 기술을 개발하거나 민간 자본을 확충하는 형식으로 민관협력이 이 루어져 왔다. 2000년 이후 미국 시카고 시와 엑슬론 (Exelon) 사는 '시카고 태양에너지 파트너십 (Chicago Solar Partnership)'을 마련하여 시카고 시내에 약 $2 \mathrm{MW}$ 규모의 태양광 설비를 설치, 연 간 1,361 톤의 이산화탄소 배출을 줄이는 효과를 보았다. 동 파트너십의 개발 당시, 미국 연방 에너 지부가 자금지원을 하였고 엑슬론 사는 태양광 발전 시스템의 구입과 설치를 위하여 1,200 만 달러 를 지원하였다 (Climate Group, 2007). 
기술개발에 집중되던 신재생에너지 분야 민관협력은 국제기구들을 중심으로 개발도상국에 대해 신 재생에너지를 지원하는 협력으로 다변화되고 있다. 신재생에너지의 개발도상국 지원은 아직 기존 의 화석연료 사용을 위한 기반이 구축되지 않은 개발도상국의 농촌전력화를 통해 지속가능개발의 글로벌화를 실현한다는 점에서 그 의의가 크다. 2000 년대 중반을 기준으로 전 세계의 에너지 분야 투자를 위해 평균적으로 연간 약 4,130억달러가 소요되었으며, 전문가들은 더 나아가 2030년까지 개발도상국과 체제전환 국가들만의 에너지를 위한 연간 투자수요가 약 3,190 억달러가 될 것으로 추정하고 있다 (World Bank, 2004). 이와 같은 개발도상국의 막대한 에너지 수요를 충족하기 위 하여 세계은행을 포함한 국제금융기관과 국제원조기구들은 민간자본의 유도를 위한 각고의 노력을 기울여 왔다.

일례로 세계은행은 에너지가격의 왜곡과 제도적인 리스크를 줄이기 위하여 정책 및 제도적 환경을 개선하고, 신재생에너지에 대한 투자를 안정적으로 제공받을 수 있도록 탄소펀드 등 민간 부문과 의 파트너십 구축을 지원하여 왔다. 또한 신재생에너지 지원 확대를 위한 민간자본 확충을 실현하 기 위하여 세계은행은 신재생에너지와 에너지효율에 적합한 사업모델을 도입하였으며, 개발도상국 내의 금융부문, 산업, 정책입안자, 소비자들의 역량과 지식을 제고하기 위하여 노력하였다 (IBRD, 2007).

한편 2002년 8월 요하네스버그에서 열린 지속가능개발 세계정상회의 (WSSD)에서 영국이 주도하 고 다른 정부, 민간기업, $\mathrm{NGO}$ 들이 참여하여 신재생에너지 및 에너지효율 파트너십 (Renewable Energy and Energy Efficiency Partnership, REEEP)을 결성하였다. REEEP는 2004년부터 적 법한 국제 $\mathrm{NGO}$ 의 지위를 획득했으며, 그 결과 영국, 노르웨이, 아일랜드, 이탈리아, 뉴질랜드 등 의 정부로부터 상당한 수준의 자금지원을 받아 100 건 이상의 프로젝트를 지원할 수 있었다. 현재 $\mathrm{REEEP}$ 에는 각 국의 정부, 기업, 원조기관, 국제금융기관, $\mathrm{NGO}$ 등의 약 300 여개 파트너가 참여 하고 있다.

\section{2. 탄소펀드 (Carbon Fund)}

탄소펀드란 금융시장에서 투자자로부터 자금을 조달해 펀드를 조성한 후, JI 또는 CDM과 같은 온 실가스 저감사업이나 배출권에 투자하는 펀드를 말한다. JI 시장은 규모와 성장 잠재력이 상대적으 로 작기 때문에 현재 대부분의 탄소펀드는 $\mathrm{CDM}$ 사업이나 이로 인해 발생한 $\mathrm{CER}$ 에 투자되고 있는 실정이다. 즉, 조달된 펀드를 $\mathrm{CDM}$ 사업에 투자하고 여기서 발생하는 $\mathrm{CER}$ 을 판매하여 수익을 투 자자들에게 배당하는 절차를 주로 따르고 있으며 (그림 1), 또는 단순히 CER을 선물 형태로 매입한 후 재판매한 차익으로 수익을 올리는 방식도 있다. 
〈그림 1〉 탄소펀드 추진 절차

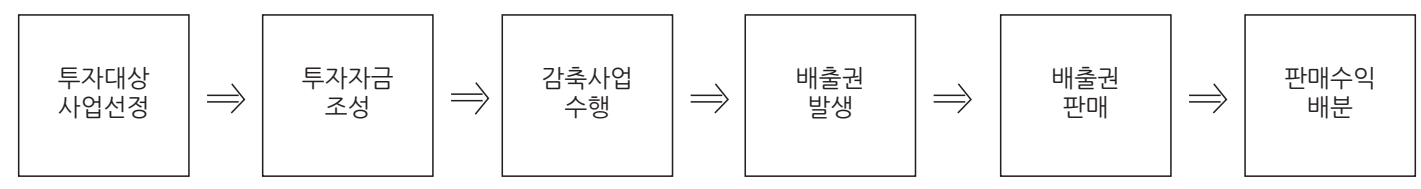

현재 전 세계에서 약 30 여개 이상의 탄소펀드가 운영 중이며, 이들 중에는 세계은행 등 국제 금융 기관이 운영하거나 유럽 국가들과 일본 등 선진국 정부 혹은 해당국의 금융기관이 운영하는 공적기 금 및 민관혼합펀드가 있다. 또한 순수 민간기관이 운영하는 민간펀드의 형태도 있다. 이들 탄소펀 드는 동아시아 등의 태평양 연안 지역에 주로 투자하고 있으며, 그 외 라틴 아메리카, 유럽, 중앙아 시아, 아프리카 순으로 투자가 이루어지고 있다.

\section{가. 세계은행의 탄소펀드}

탄소펀드는 2000년 4월 세계은행이 Prototype Carbon Fund (PCF)를 조성하여 기업이나 정부로 부터 받은 기부금을 JI나 $\mathrm{CDM}$ 프로젝트에 투자한 것으로 시작하였다. 세계은행은 현재 $\mathrm{PCF}$ 를 포 함하여 총 13 개의 탄소펀드를 운영하고 있으며 (표 1), 2008년 말을 기준으로 23 억달러 이상의 탄 소자산 가치에 해당하는 186건의 프로젝트를 이들 펀드의 포트폴리오에서 관리하고 있다 (Carbon Finance Unit, 2009).

투자금액은 2005년 교토의정서의 발효 이후 괄목할 만한 증가세를 보여, 이 때 처음으로 10 억달러 이상의 규모를 갖추게 되었다 (그림 2). 지역적으로는 중국에 대한 대규모 투자에 힘입어 동아시아 및 태평양 연안에서 가장 많은 투자 (전체의 $71 \%$, 총 13 억달러 가치 이상의 배출감소분)가 이루어 져 왔다 (그림 3). 또한 펀드가 투자한 기술 종류의 분포를 살펴보면, $\mathrm{HFC}-23^{5)}$ 기술의 프로젝트가 가장 큰 비중 (54\%)을 차지하고 그 뒤를 에너지효율 기술 $(10 \%)$ 이 이어가고 있는 상황이지만, 최 근 신재생에너지 및 에너지효율 기술, 폐기물 관리의 프로젝트가 급증하면서 HFC-23 프로젝트에 대한 투자 비중은 지속적으로 감소하고 있다 (Carbon Finance Unit, 2009).

5) Fluoroform. 에어컨용 냉매인 HCFC-22를 생산하는 과정에서 발생하는 온실가스로서, 단위 당 온난화 능력 (GWP)이 이산 화탄소의 11,700 배임. 
〈그림 2〉 세계은행이 관리하는 탄소펀드 및 기구의 투자금액의 증가 추세

(단위 : 백만달러)

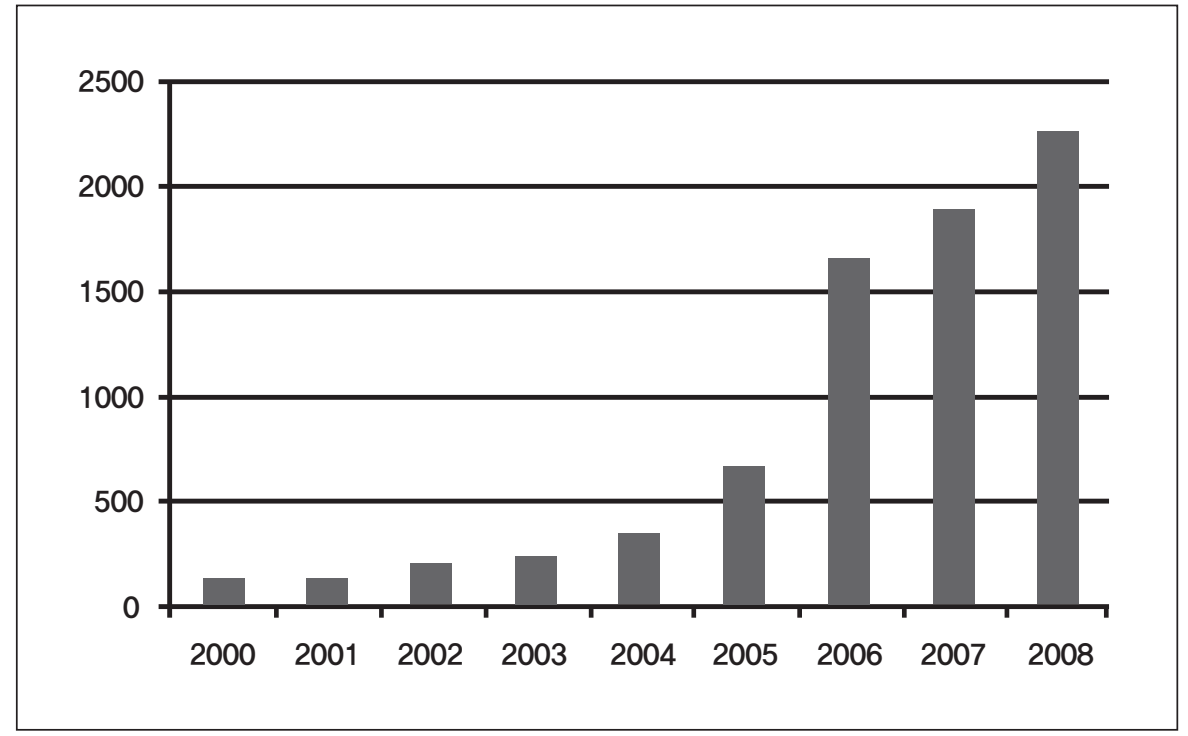

*금액이 공개되지 않은 NCDMF 및 NECF는 제외 Source: Carbon Finance Unit (2009)

〈그림 3〉 탄소배출 감소분에 대한 화폐 가치의 지역적 분포

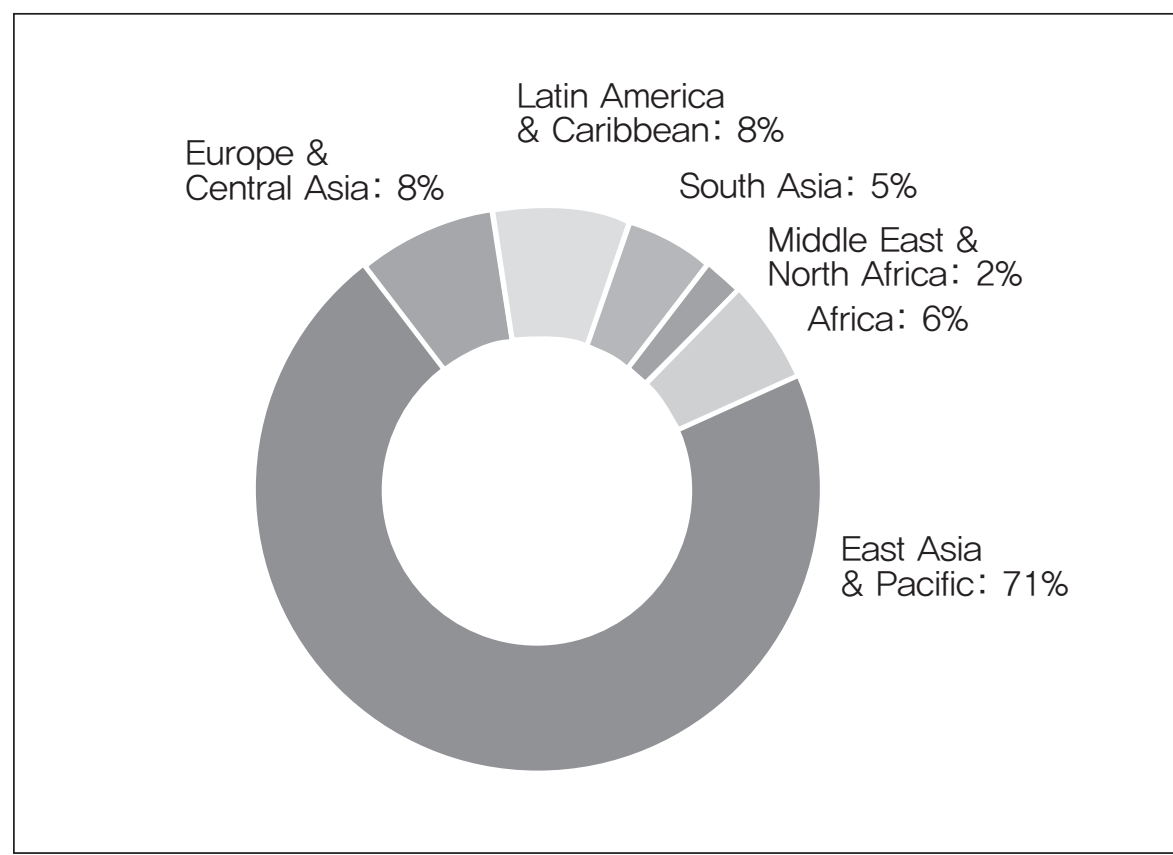

Source: Carbon Finance Unit (2009) 


\section{〈표 1〉 세계은행 탄소펀드 운영 현황}

\section{국별 민간기관 참여 수}

\begin{tabular}{|c|c|c|}
\hline $\begin{array}{l}\text { · } 17 \text { 개 민간기업 } \\
\text { - 일본(8), 노르웨이(2), 독일(2), 네덜란드(1), 벨기에(1), } \\
\text { 영국(1), 프랑스(1), 핀란드(1) }\end{array}$ & 57.6 & 세계 최초의 탄소펀드로 온실가스 저감 프로젝트 선도 \\
\hline $\begin{array}{l}\text { · 15개 민간기업 } \\
\text { - 일본(5), 스페인(3), 노르웨이(2), 독일(1), 스웨덴(1), } \\
\text { 스위스(1), 포르투갈(1), 핀란드(1) }\end{array}$ & 45.1 & $\begin{array}{l}\text { UNO 지정한 최빈국 및 세계은행의 IDA 목록에 있는 저개발 국가 } \\
\text { 들을 우선적으로 지원하고 이들의 지역 환경 개선에 기여 }\end{array}$ \\
\hline $\begin{array}{l}\text { · } 9 \text { 개 민간기업 } \\
\text { - 일본(8), 프랑스(1) }\end{array}$ & 51 & $\begin{array}{l}\text { 산림, 농경지 또는 기타 생태계에서 발생하는 온실가스의 분리 및 } \\
\text { 흡수 프로젝트에 투자 }\end{array}$ \\
\hline $\begin{array}{l}\text { · } 4 \text { 개 민간기업 } \\
\text { - 미국(1), 스위스(1), 스페인(1), 영국(1) }\end{array}$ & 47 & $\begin{array}{l}\text { 산림, 농경지 또는 기타 생태계에서 발생하는 온실가스의 분리 및 } \\
\text { 흡수 프로젝트에 투자 }\end{array}$ \\
\hline & & $\begin{array}{l}\text { 세계은행이 운영하는 탄소펀드와 기타 참여자들을 모집하여 대규 } \\
\text { 모 프로젝트에서 배출권을 구매하는 기구 }\end{array}$ \\
\hline- & 0 & 개발도상국 CDM 사업에 투자하고 배출권 구매하기 위한 기구 \\
\hline · 6 개 이탈리아 민간기업 & 30.2 & 비용 효율적인 온 실가스 배출 저감과 청정기술 도입 프로젝트에 투자 \\
\hline- & 0 & 동유럽국가에서의 Jl 사업으로부터 발생한 감축분 구매 \\
\hline · 4개 덴마크 민간기업 & 78 & $\mathrm{CDM}$ 및 $\mathrm{J}$ 사업에 투자 \\
\hline · 12 개 스페인 민간기업 & 22.7 & 에너지효율 향상 및 신재생에너지 사업의 지원 \\
\hline- & 0 & 에너지효율 향상 및 신재생에너지 사업의 지원 \\
\hline · 1개 노르웨이 민간기업 & 20 & 유럽국가들의 교토의정서 수행을 돕기 위해 고안된 펀드 \\
\hline- & 0 & 개발도상국 CDM 사업에 투자하고 배출권 구매하기 위한 기구 \\
\hline · 6개 이탈리아 민간기업 & 30.2 & 비용 효율적인 온실가스 배출 저감과 청정기술 도입 프로젝트에 투자 \\
\hline- & 0 & 동유럽국가에서의 Jl 사업으로부터 발생한 감축분 구매 \\
\hline · 4개 덴마크 민간기업 & 78 & CDM 및 Jl 사업에 투자 \\
\hline · 12개 스페인 민간기업 & 22.7 & 에너지효율 향상 및 신재생에너지 사업의 지원 \\
\hline- & 0 & 에너지효율 향상 및 신재생에너지 사업의 지원 \\
\hline · 1 개 노르웨이 민간기업 & 20 & 유럽국가들의 교토의정서 수행을 돕기 위해 고안된 펀드 \\
\hline
\end{tabular}

${ }^{*} €$ million

* $\mathrm{UCF}$ 의 자본금은 PCF, NCDMF, ICF, DCF, 및 SCF의 €224.54 million 투자금액 포함 


\begin{tabular}{|c|c|c|c|}
\hline 펀드명 & $\begin{array}{c}\text { 자본금 } \\
\text { (US\$ million) }\end{array}$ & 설립일 & 정부기관 참여 현황 \\
\hline \multicolumn{4}{|l|}{ Pioneering Fund } \\
\hline Prototype Carbon Fund (PCF) & 180.0 & 2000.4 & $\begin{array}{l}\text { · } 5 \text { 개 국가정부 및 } 1 \text { 개 개발기관 } \\
\text { - 캐나다. 핀란드, 노르웨이, 스웨덴, 네덜란드 정부 } \\
\text { - JICA (일본) }\end{array}$ \\
\hline \multicolumn{4}{|l|}{ Specialized Funds } \\
\hline $\begin{array}{l}\text { Community Development Carbon } \\
\text { Fund (CDCF) }\end{array}$ & 128.6 & 2003.3 & $\begin{array}{l}\text { · } 7 \text { 개 국가정부, } 2 \text { 개 지방정부 및 } 1 \text { 개 개발기관 } \\
\text { - 오스트리아, 캐나다, 덴마크, 이탈리아, 룩셈부르크, 스페인, } \\
\text { 네덜란드 정부 } \\
\text { - 브뤼셀(벨기에), 왈룬(벨기에) 지방정부 } \\
\text { - KfW (독일) }\end{array}$ \\
\hline \multirow{2}{*}{$\begin{array}{l}\text { BioCarbonFund (BioCF), } \\
\text { 1. Tranche1 } \\
\text { 2. Tranche2 }\end{array}$} & 53.8 & 2004.5 & $\begin{array}{l}\cdot \text { 4개 국가정부 및 1개 개발기관 } \\
- \text { 캐나다, 이탈리아, 룩셈부르크, 스페인 정부 } \\
\text { - AfD (프랑스) }\end{array}$ \\
\hline & 38.1 & 2007.3 & $\begin{array}{l}\text { - } 2 \text { 개 국가정부 및 } 1 \text { 개 개발기관 } \\
- \text { 아일랜드, 스페인 정부 } \\
\text { - } \mathrm{AfD} \text { (프랑스) }\end{array}$ \\
\hline \multicolumn{4}{|l|}{ Umbrella Fund } \\
\hline Umbrella Carbon Facility (UCF) & $799.1+^{*}$ & 2006.8 & \\
\hline \multicolumn{4}{|l|}{ Country Funds } \\
\hline $\begin{array}{l}\text { Netherlands CDM Facility } \\
\text { (NCDMF) }\end{array}$ & NA & 2002.5 & · 네덜란드 정부 \\
\hline Italian Carbon Fund (ICF) & 155.6 & 2004.3 & · 이탈리아 정부부처 (환경국토해양부) \\
\hline $\begin{array}{l}\text { Netherlands European Carbon } \\
\text { Facility (NECF) }\end{array}$ & NA & 2004.8 & · 네덜란드 정부부처 (경제부) \\
\hline Danish Carbon Fund (DCF) & $90+$ & 2005.1 & $\begin{array}{l}\text { · 2개 덴마크 정부부처 } \\
\text { - 외교부 및 환경부 }\end{array}$ \\
\hline \multirow{2}{*}{$\begin{array}{l}\text { Spanish Carbon Fund (SCF) } \\
\text { 1. Tranche1 } \\
\text { 2. Tranche2 }\end{array}$} & $220+$ & 2005.3 & $\begin{array}{l}\cdot 2 \text { 개 스페인 정부부처 } \\
- \text { 환경농촌어업부 및 경제재정부 }\end{array}$ \\
\hline & $220+$ & 2008.4 & $\begin{array}{l}\text { 2개 스페인 정부부처 } \\
- \text { 경제재정부 및 환경농촌어업부 }\end{array}$ \\
\hline Carbon Fund for Europe (CFE) & $50+$ & 2007.3 & $\begin{array}{l}\text { · } 4 \text { 개 국가정부 } \\
\text { - 포르투갈, 아일랜드, 룩셈부르크, 벨기에 }\end{array}$ \\
\hline \multicolumn{4}{|l|}{ Country Funds } \\
\hline $\begin{array}{l}\text { Netherlands CDM Facility } \\
\text { (NCDMF) }\end{array}$ & NA & 2002.5 & · 네덜란드 정부 \\
\hline Italian Carbon Fund (ICF) & 155.6 & 2004.3 & · 이탈리아 정부부처 (환경국토해양부) \\
\hline $\begin{array}{l}\text { Netherlands European Carbon } \\
\text { Facility (NECF) }\end{array}$ & NA & 2004.8 & · 네덜란드 정부부처 (경제부) \\
\hline Danish Carbon Fund (DCF) & $90+$ & 2005.1 & $\begin{array}{l}\text { · 2개 덴마크 정부부처 } \\
\text { - 외교부 및 환경부 }\end{array}$ \\
\hline \multirow{2}{*}{$\begin{array}{l}\text { Spanish Carbon Fund (SCF) } \\
\text { 1. Tranche1 } \\
\text { 2. Tranche2 }\end{array}$} & $220+$ & 2005.3 & $\begin{array}{l}\cdot 2 \text { 개 스페인 정부부처 } \\
- \text { 환경농촌어업부 및 경제재정부 }\end{array}$ \\
\hline & $70+$ & 2008.4 & $\begin{array}{l}\text {. } 2 \text { 개 스페인 정부부처 } \\
\text { - 경제재정부 및 환경농촌어업부 }\end{array}$ \\
\hline Carbon Fund for Europe (CFE) & $50+$ & 2007.3 & $\begin{array}{l}\cdot 4 \text { 개 국가정부 } \\
- \text { 포르투갈, 아일랜드, 룩셈부르크, 벨기에 }\end{array}$ \\
\hline
\end{tabular}


가장 최근에 형성된 펀드로는 2007년에 세계은행 위원회가 승인하고, 같은 해 12 월 발리에서 착수 한 산림탄소파트너십기구 (Forest Carbon Partnership Facility, FCPF)와 2008년 10월부터 시 작된 탄소파트너십기구 (Carbon Partnership Facility, $\mathrm{CPF}$ )가 있다. 두 파트너십 기구들은 단순 한 탄소펀드의 차원을 넘어서서, 보다 더 특화된 분야에서 자금을 효과적이면서도 전문적으로 끌어 들이고 운영하기 위하여 결성되었다. 즉 기구 안에는 탄소펀드 이외에 다른 구성 요소들도 존재하 여 기능을 담당하고 있다. $\mathrm{FCPF}$ 는 산림 벌채 및 황폐화에 의한 탄소 배출을 감소시키려는 목적 하 에 결성된 펀드로서, 현재 총 37 개국에서의 $\mathrm{REDD}$ 프로젝트를 지원하고 있다. $\mathrm{CPF}$ 는 탄소크레딧 의 구매자와 공급자 간의 협력체이며, 단일 프로젝트 뿐 만 아니라 프로그램에 대한 투자도 가능하 다.

탄소펀드의 제도적인 측면에서, 세계은행은 최근까지 최초의 탄소펀드 (PCF) 출시, 특화된 분야 의 탄소펀드 $(\mathrm{CDCF}, \mathrm{BioCF})$ 형성, 새로운 파일럿 펀드 $(\mathrm{CPF}, \mathrm{FCPF})$ 시도 등을 주도해 왔다. 또 한 세계은행은 초기의 탄소시장에서 시장 촉매제 역할을 수행하여 왔으며, 프로그램 중심의 $\mathrm{CDM}$ 및 $\mathrm{REDD}$ 방법론 등 탄소시장의 새로운 사업모델 개발에도 공헌하였다. 특히 세계은행은 산림분야 $\mathrm{CDM}$ 방법론 개발에 대한 공헌이 높은 것으로 평가된다 (표 2).

아울러 향후 10 년의 탄소시장을 위해서 세계은행은 장기적인 관점에서 저탄소 경제사회로의 이전 에 중점을 두고 탄소펀드를 운영할 계획이다. 특히 세계은행은 그 동안 단일 프로젝트 중심으로 펀 드를 조성했던 근시안적인 운영에서 벗어나, 프로젝트를 연계하여 전략적으로 지원하는 형식의 시 스템적인 프로그램의 투자방식을 채택할 예정이다. 이를 위해 탄소가격의 시그널을 제공하는 장기 적 제도의 틀을 구축하고, 저탄소 기술 개발을 촉진하는 유인책을 공급할 계획에 있다. 한편 세계은 행은 향후 10 년 동안 산림벌채 방지를 위한 인센티브의 제공에도 큰 관심을 기울이고 있다.

〈표 2〉 UNFCCC가 승인한 CDM 방법론의 건수

\begin{tabular}{c|c|c}
\hline & 세계은행 (\%) & 전 세계 합계 \\
제출된 방법론 개수 & $46(20 \%)$ & 10 \\
\hline 승인된 산림 프로젝트 방법론 개수 & $7(70 \%)$ & 63 \\
\hline 승인된 타 분야 프로젝트 방법론 개수 & $17(27 \%)$ & 63 \\
\hline
\end{tabular}

\section{나. 기타 국제 탄소펀드}

아시아개발은행 $(\mathrm{ADB})$ 은 청정에너지 분야의 역량, 제도, 프로젝트 개발 활동을 지원하기 위한 펀 드 및 파트너십 등의 신탁기금을 설치하였으며, 아 - 태 탄소펀드 (Asia Pacific Carbon Fund, 
$\mathrm{APCF}$ ), 청정에너지 자금지원 파트너십기구 (Clean Energy Financing Partnership Facility, $\mathrm{CEFPF}$ ), 기후변화펀드 (Climate Change Fund, $\mathrm{CCF}$ ), 미래탄소펀드 (Future Carbon Fund) 등 을 운영 중이다.

이들 중 $\mathrm{CEFPF}$ 는 신재생에너지 및 에너지효율 부문의 지원을 위한 정책이나 제도 환경의 구축을 위하여 2 억5천만달러의 목표 금액을 설정하고 설립된 펀드기구이다. 기구 내에는 호주, 노르웨이, 스페인, 스웨덴 정부의 지원을 받는 청정에너지펀드 (Clean Energy Fund, CEF)와 일본 정부의 지원을 받는 Asian Clean Energy Fund (ACEF)의 두 가지 펀드가 있다.

유럽부흥개발은행 (European Bank for Reconstruction and Development, EBRD)은 2003 년 10월에 네덜란드 정부와 공동으로 네덜란드 배출감축 탄소펀드 (Netherlands Emissions Reductions Co-operation Fund)를 조성하여 유럽지역의 첫 탄소펀드를 출시하였다. 동 펀드는 3,500 만 유로 규모의 투자금액을 목표로 하여, 사업 우선 대상인 13 개국)에서 수행되는 JI 프로 젝트에서 발생하는 탄소 크레딧을 구매하는 것을 내용으로 하고 있다. 이후 EBRD가 유럽투자은 행 (European Investment Bank)과 공동으로 2006년부터 운영하기 시작한 탄소 크레딧 다자 펀 드 (Multilateral Carbon Credit Fund)는 중앙유럽과 중앙아시아 지역을 타겟으로 1억9천만 유로 의 금액을 펀드 참여자로부터 약정 받았다. 동 펀드에는 핀란드, 벨기에, 아일랜드, 룩셈부르크, 스 페인, 스웨덴의 6 개 국가 정부와 6 개 민간기업들 ${ }^{7)}$ 이 참여하고 있다. 에너지 효율향상, 신재생에너 지, 탄소집중도가 낮은 에너지로의 변환, 온실가스 흡수원 등이 동 펀드의 투자대상 사업에 해당한 다. 이 외에도 $\mathrm{EBRD}$ 는 벨기에 정부와 함께 4천만 유로 규모의 에너지 효율화 배출삭감 펀드를 조 성하였다.

\section{다. 국내 탄소펀드}

우리나라의 2006년 이산화탄소 배출량은 총 4.8억 $\mathrm{CO}_{2}$ 톤으로, 이는 전 세계 이산화탄소 배출량의 $1.7 \%$ 에 해당하는 양이다 (IEA, 2008). 즉 전 세계 국가들 중 상위 9 위 또는 $\mathrm{OECD}$ 국가들 중에서 는 상위 6 위의 이산화탄소 다배출 국가이이면서도 교토의정서 상의 온실가스 감축의무를 이행하지 않고 있는 우리나라는, 포스트 교토제제에서는 그 의무를 부담해야 하는 국제적인 압박을 받고 있 다.

6) 에스토니아, 불가리아, 크로아티아, 체코, 헝가리, 라트비아, 리투아니아, 폴란드, 루마니아, 러시아, 슬로바키아, 슬로베 니아, 우크라이나

7) Zeroemissions (Spain), CEZ (Czech Republic), Endesa (Spain), Gas Natural (Spain), PPC (Greece), Union Fenosa (Spain)

8) 2006년 이산화탄소 주요배출국은 미국 $20.3 \%$, 중국 $20.0 \%$, 러시아 $5.7 \%$, 인도 $4.5 \%$, 일본 $4.3 \%$ 순이다. 
이러한 환경에서 국내에서도 포스트 교토체제에서 우리나라가 온실가스 감축의 의무를 지게 되는 경우 발생할 본격적인 탄소 배출권 거래에 대비하는 동시에, 국내 온실가스 감축 기술 및 금융기관 을 육성하기 위하여 국내 탄소펀드 도입의 필요성이 제기되어 왔다. 그 결과 2007년 8월 당시 산업 자원부 (현, 지식경제부)와 한국투자신탁운용이 2,000억원 규모의 국내 1호 탄소펀드인 '한국사모 탄소 특별자산 1호'를 출시한 이래, 2008년 8월 보성 및 창녕의 $1 \mathrm{MW}$ 급 태양광발전사업 2건에 대 한 투자를 시작으로 $\mathrm{CDM}$ 사업 및 탄소배출권에 투자하고 있다.

국내 1호 탄소펀드가 주로 국내 $\mathrm{CDM}$ 사업 지원에 대해 중점적으로 투자해 온 반면, 최근에 수출입 은행이 설립 계획 중인 신규 탄소펀드는 신재생에너지 등의 분야에서 국내 기업들의 해외 진출 활 성화를 지원하는 것을 주된 내용으로 한다. 즉, 민관합동으로 조성될 신규 펀드는 국내 기업이 해외 에서 추진하려고 하는 $\mathrm{CDM}$ 사업에서 발생되는 $\mathrm{CERs}$ 를 미리 매입하고 ${ }^{9}$, 탄소펀드가 투자하는 사 업에 수출입은행이 금융을 제공하는 방식으로 운용될 전망이다. 이를 위해 수출입은행은 올해 9월 말까지 1,000 억원 규모의 탄소펀드를 설립하기로 하고, 한국투자신탁운용을 펀드의 위탁운용사로 선정하여 투자자를 모집 중이다. 수출입은행은 전체 금액 중 $15 \%$ 인 150 억원을 출자했으며, 이 외 에 정부부처와 공공기관, 민간기업들이 펀드에 참여할 것으로 기대된다.

\section{IV. 적응 분야의 민관협력 현황}

기후변화 적응에서의 민관협력을 전통적인 $\mathrm{ODA}$ 분야이면서 기후변화로 인해 그 중요성이 더욱 커 진 물 분야와 새롭게 떠오르는 기후위험보험(climate risk insurance) 분야에서 살펴보도록 하겠 다.

\section{1. 물 분야 민관협력}

수자원 공급 및 위생처리(Water Supply and Sanitation, WSS) 분야는 대규모의 설비투자비가 요 구되므로 전통적으로 $\mathrm{PPP}$ 의 중요성이 강조된 분야이다. 많은 국가들은 오래전부터 WSS 시설의 운 용, 현대화, 확장을 위해서 민간부분을 끌어들이고 있으며 이러한 $\mathrm{PPP}$ 의 역사는 일부 선진국에서 백년이 넘어간다. 대부분의 개도국은 10 20여년 정도의 경험을 가지고 있으며 동일 기간 동안 선 진국을 포함하여 전 세계적으로 진행되고 있는 $\mathrm{PPP}$ 를 활용한 물 관련 프로젝트 수와 규모는 꾸준

9) CER은 보통 사업 개시로부터 2 3년 후 UN의 인증절차를 거쳐 발행되는 것이 보통이나, CER 발행 이전에도 선도거래를 통해 매매가 가능하므로, 이를 통해 사업초기에 필요한 자금을 일부 조달할 수 있다. 단, CER의 선구매는 많은 리스크를 가지고 있어 수익을 추구하는 민간탄소펀드와의 거래는 어려움이 있지만, 공공탄소펀드는 사업초기 단계에서의 CER 선구 매도 가능하다 (한국수출입은행, 2009) 
히 증가하여왔다. 관련 프로젝트의 누적투자비용은 1992년 20억 달러였으나 2000년에 350억 달 러로 크게 증가하였으며 (OECD, 2003) 1985년부터 1999년까지 민간의 참여에 의해 진행되어온 물 분야의 프로젝트 개수도 이와 병행하여 증가하였다. (그림 4). 그러나 신흥시장에서의 물 관련 $\mathrm{PPP}$ 가 최근 들어 문제를 겪고 있는 사례가 보고되면서 일부 민간기업들이 이들 국가에서 철수하는 사건이 발생하였다

\section{〈 그림 4〉물 분야에서 민간의 참여에 의한 프로젝트 개수}

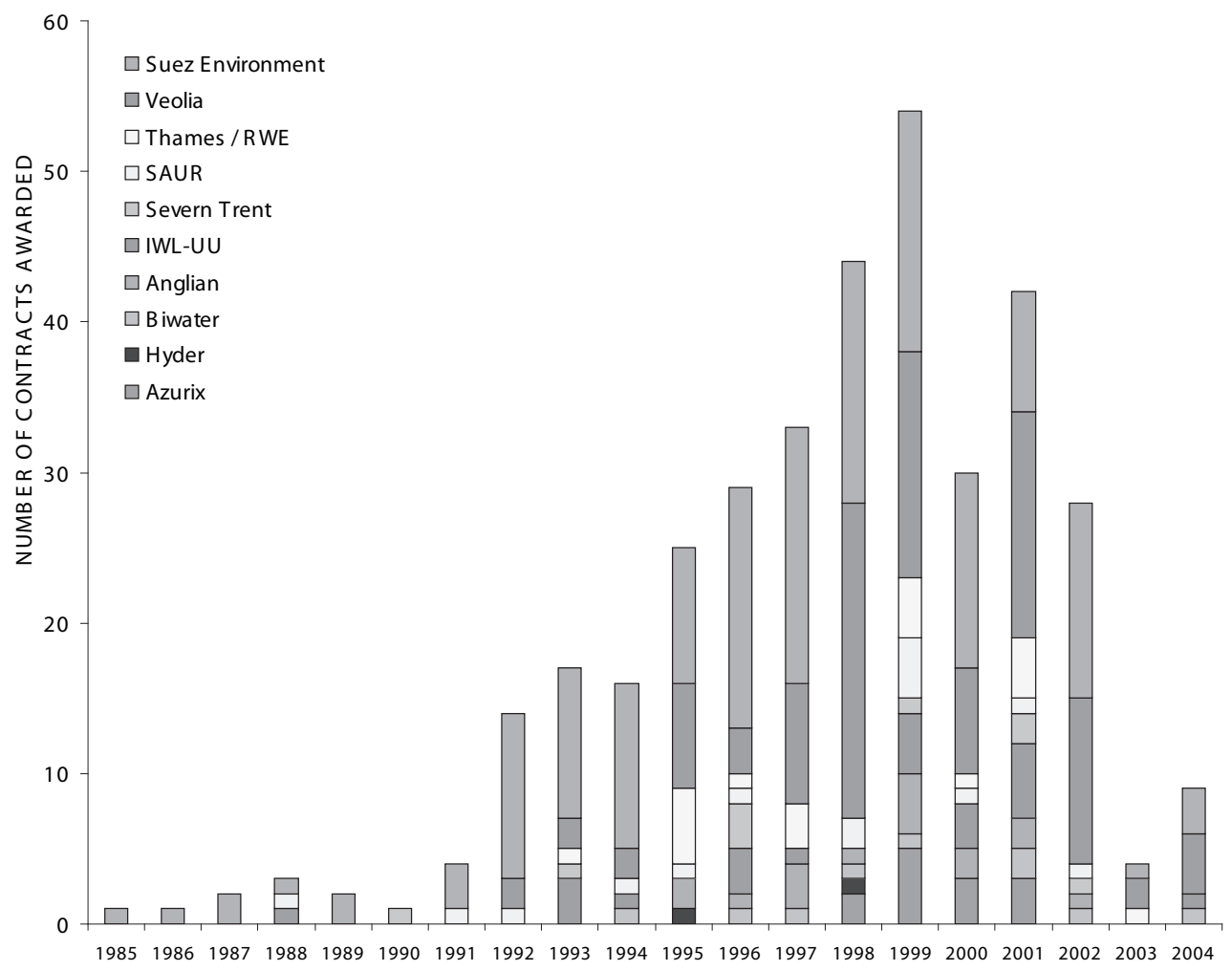

출처: Mathys, 2006

물 분야에서 민간부분의 활용은 인프라 구축을 위한 디자인과 건설에만 참여하고 소유와 경영은 공 공의 손에 맡기는 방식부터 민간이 관리, 운영 및 자금 조달까지 하는 방식까지 그 범위가 매우 다 양하다. 〈표 3〉에 이를 더 자세히 설명하였다. 물 분야에서 $\mathrm{PPP}$ 는 수처리시설의 운영 및 소유권 이 민간부분으로 이전되는 민영화와는 구분되어야한다. 따라서 민간이 참여하더라도 정부는 안 전하며 효율적인 물 공급이 이루어지고 독과점에 의한 폐해가 발생하지 않도록 그 책임을 다해야 한다. $\mathrm{OECD}$ 는 WSS 분야에서 정부가 공공과 민간의 역량을 최대로 활용하는데 지침이 되도록 ‘Checklist for Public Action'을 발표하였다. 이것은 역할, 위험, 책임 배분을 포함한 정책 방향을 제시하고 민간 참여를 최대한 활용하기 위한 구조적 틀을 포함한다(OECD, 2009b). 
〈표 3〉 물 분야에서 민간의 참여방식에 따른 공공/민간의 책임구분

(검정: 공공 책임, 회색: 공공/민간의 공동 책임, 흰색: 민간 책임)

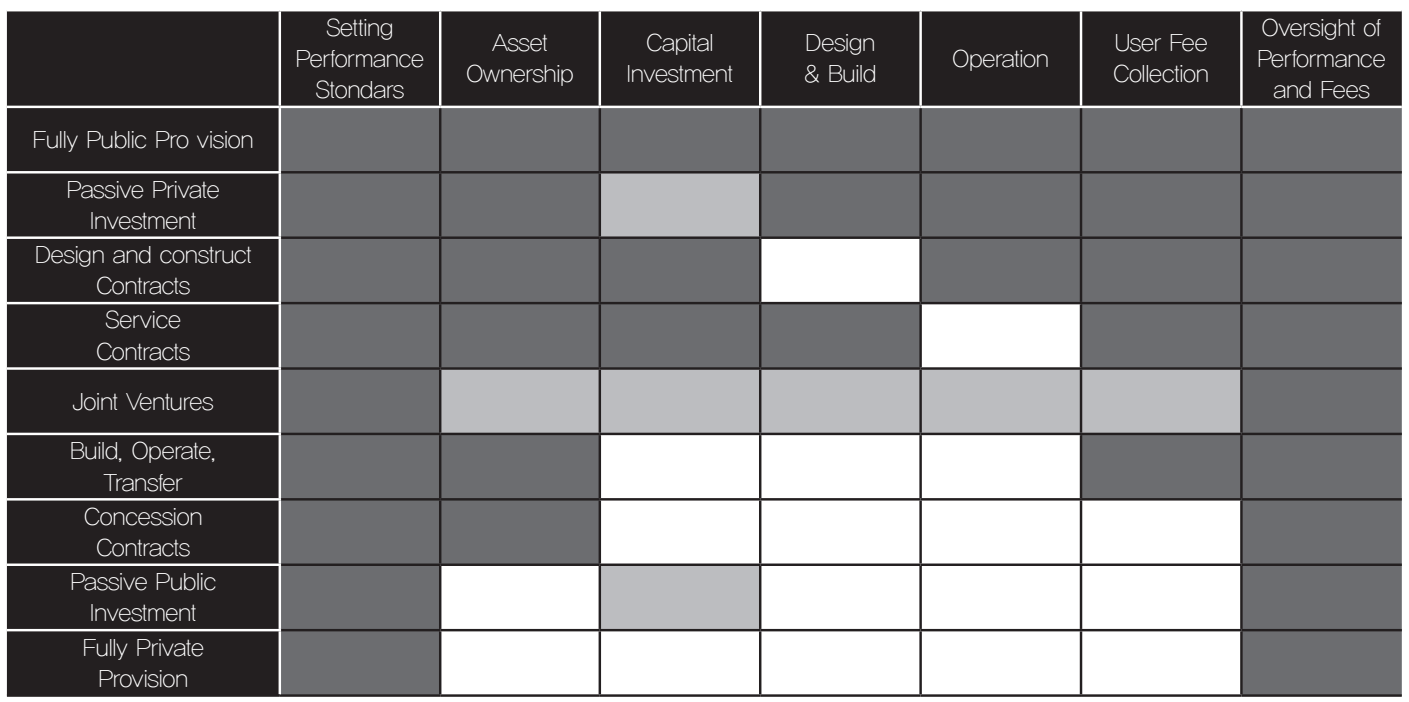

출처: OECD (2000) Global Tends in Urban Water Supply and Waste Water Financing and Management : Changing Roles for the Public and Private Sector, Paris

$\mathrm{OECD}$ 의 예측에 의하면 물 관련 MDGs를 달성하기 위해서는 매해 180 억 달러의 비용이 필요하 며 기존 시설의 유지 및 개보수를 위해서는 해마다 540억 달러가 소요될 것이라고 한다(OECD, 2009c). 그러나 현실적으로 필요한 비용과 조달할 수 있는 비용 사이에는 커다란 격차가 존재한다. 예로 에티오피아는 2006년 22\%에 달하는 안전한 식수에 대한 접근 비율을 2012년까지 98\%로 증 가시키는 ‘Universal Access Programme’을 발표하였으나 이를 어떻게 재정적으로 뒷받침할 것 인가에 대한 방안은 매우 불투명한 상황이다. 이와 같은 물 관련 지원의 막대한 비용 규모를 고려 하면 $\mathrm{ODA}$ 의 역할은 기본적인 것에 제한될 수밖에 없고 수원국 내에서 세금, 사용자가 지불하는 요 금, 민간 투자 등 ODA 외의 방식을 통한 자금 마련 방안을 반드시 논의해야 한다. 〈그림 5〉는 프랑 스, 한국, 멕시코, 에티오피아, 모잠비크 등의 국가에서 물 분야 사업의 재원의 충당에 있어서 사용 자가 지불하는 요금(tariffs), 정부가 지불하는 세금을 통해 마련된 재원(taxes), ODA를 포함한 외 부 자금(transfers)의 비율을 나타낸다 ${ }^{10)}$. 프랑스와 같은 선진국에서는 사용자가 전체 재원의 $90 \%$ 이상을 충당하고 있지만 국가 재정상태가 어려운 모잠비크와 같은 빈곤국은 ODA가 중요한 역할을 한다. 최빈국보다 상황이 나은 멕시코, 이집트 같은 개발도상국들은 세금의 비중이 매우 높음을 알 수 있다.

10) 이를 $3 T s$ 라 일컬음. 


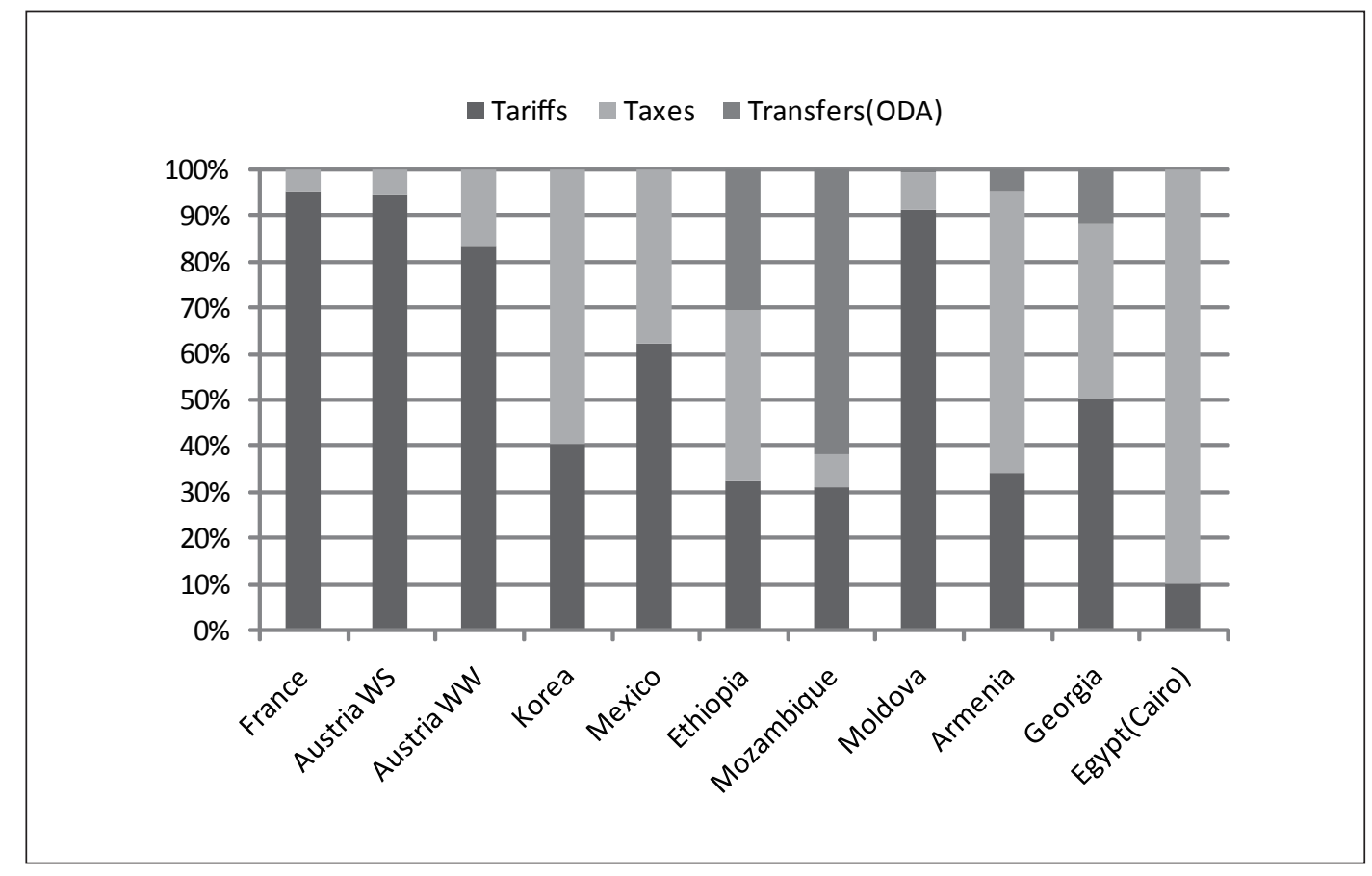

이처럼 물 분야의 사업은 출처가 다양한 자금을 필요로 하는데 이 때 관련 자금의 배분과 효과적인 사용을 위해 이용할 수 있는 도구가 바로 '전략적 재원 계획(Strategic Financial Planning)'이다 $(\mathrm{OECD}, 2009 \mathrm{c})$. 전략적 재원 계획이란 올바른 정보와 분석, 다양한 이해관계자의 참여를 통하여 공공예산과 일반 가구들이 감당할 수 있는 실현 가능한 목표를 수립하는 것으로(박희수 외, 2009), WSS 건설사업을 위해서 활용가능한 공공자금의 규모를 파악하고 상하수도 요금을 이자와 감가상 각까지 포함한 여러 비용을 고려하여 잠정적으로 정한 뒤 상수도 요금을 납부하는 해당 마을 주민 과의 공청회 등을 통하여 그들이 감당할 수 있는 수준으로 새로운 요금을 정하는 일련의 과정을 일 컫는다. 또한 물이 지닌 공공성에 기초하여 새롭게 정해진 요금조차 감당할 수 없는 빈곤층은 정부 가 지원을 하는 것을 포함하며 추후 민간에 의한 지속적인 투자가 이루어질 수 있도록 자본금 회수 와 운영 및 관리비용의 충당을 달성하기 위해서 높은 요금징수율을 거둔 직원에게는 격려금을 지급 하는 방법 등을 사용한기도 한다.

물 분야에서 민간부분의 투자가 병행되기 위해서는 개도국 내에서 물과 관련된 모든 부분에서 효율 적인 운용 및 관리가 필수조건이다. 물 분야의 사업들은 초기 투자비용이 높고 이를 회수할 수 있는 기간이 매우 길고 투자에 따른 기대 이익이 낮기 때문에 민간 업자들은 투자 환경이나 위험의 정도 
에 매우 민감하다. 따라서 사업 추진 시 투명성과 신뢰성이 확보되어야 하며 수원국의 정치적 안정 및 효율적인 운영 시스템도 병행되어야한다. 특히 여러 관련 분야를 아우르는 통합적인 접근법과 이해당사자들 간의 충분한 대화가 반드시 뒤따라야한다.

민간자금을 끌어올 수 있도록 해당 분야의 위험 관리 메카니즘의 개발과 사용을 지원하는 것이 또 다른 ODA의 역할이다. 이러한 사업의 예로 USAID와 JICA의 지원으로 수행된 Philippine Water Revolving Fund(PRWF)를 들 수 있다. 필리핀은 물 분야에서 심각한 문제점을 가지고 있는 국가 이다. 전인구의 $44 \%$ 만이 수도관으로부터 식수 공급을 받고 있으며 $4 \%$ 의 인구가 하수처리시스템에 접근할 수 있고 폐수처리장이 없다. 공공기금은 MDGs를 달성하기 위해 필요한 자금의 절반 정도 만을 감당할 수 있으며 국가 재정과 ODA가 물관련 사업을 위한 자금의 원천이었으나 과거 십년 동 안 감소하여왔다. 따라서 이러한 문제를 해결하기 위해 필리핀 정부는 민간투자를 끌어들이는데 관 심을 가지게 되었다. 먼저 필리핀 정부의 보증은 공공은행이 $\mathrm{ODA}$ 자금을 직접 빌릴 수 있도록 하 였으며 이것은 민간자본을 레버리지하는 것으로 이용되었다. 다행히 필리핀의 금융시장은 유동성 이 풍부하고 금리가 낮았다. $\mathrm{PWRF}$ 는 JICA로부터의 조건부 차관과 지역의 상업 은행으로부터의 자금을 혼합하여 디자인되었다. USAID는 지급보증을 하여서 민간채권자들이 느끼는 위험부담을 줄여주었다. 부채 상환 기간도 정부의 지원으로 10 년 이상으로 늘어났다. 필리핀 정부의 새 정책 과 민간 자금기관과의 대화는 PWRF가 출범하기 전에 물 분야의 자금조달에 관심을 불러일으켰다. 2007 년 이후 민간 은행들은 총 2천3백만 달러에 이르는 대출을 제공하여왔으며 이것은 72 만여 명 의 필리핀 국민들에게 수도관에서 공급되는 물을 사용할 수 있도록 해줄 것이다(Moore, 2006).

\section{2. 기후 위험 보험 (Climate Risk Insurance)}

극단적인 기후 현상의 발생이 기후변화로 인해 더욱 예측하기 어려워지고 그 강도와 빈도가 증가하 고 있어서 열악한 국가 재정을 가진 개도국들은 매우 어려운 상황에 처해있다. 예를 들어 온두라스 의 경우 허리케인 미치(Mitch)로 인한 재건비용이 일인당 1,250 달러에 달하였는데 인구의 $70 \%$ 가 하루 2 달러로 생활하는 최빈국에서 이러한 부담은 증세를 통해 해결할 수 있는 범위를 넘어선다. 보험과 같은 메카니즘은 재난 발생 후 즉각적인 현금 흐름을 제공하고 재난의 결과로 인해 빚이 추 가적으로 축적되는 것을 피할 수 있게 해주는 효과적인 적응 전략 중의 하나이다. 또한 보험은 중장 기적으로 빈곤감소적 성장 외의 분야로 돈이 흘러가는 것을 방지해 준다.

기후변화와 관련하여 ‘보험’이라는 용어는 Alliance of Small Island States(AOSIS)에 의해 1991 년 처음 사용되었으며 기후변화협약은 제4조 8항에 보험을 개도국의 시급한 상황을 해결할 수 있 는 방안의 하나로 제시하였다 (표 4). 후에 AOSIS는 도서국가들과 저지대에 위치한 개도국이 해 
수면 상승에 의한 피해를 보상받기 위해 당사국총회(Conferences of the Parties)의 감독 하에 부 속서 II 국가들이 'International insurance pool'을 만들 것을 제안하였다(Linnerooth-Bayer 와 Mechler, 2006). 세계은행의 'World Development Report of 2000/2001'은 취약성을 감소 시키고 단기 회복을 위한 수단으로써의 보험의 역할에 관심을 보였으며 IPCC와 기후변화에 취약 한 개도국들은 보험이 기후변화 적응의 도구로 중요한 요소임을 인식하기 시작하였다. 특히 기후 변화 적응에 대한 깊이 있는 분석은 IPCC의 3차보고서에서 찾아볼 수 있는데 이 보고서는 먼저 적 응을 8개로 분류하고 그 중에서 '손실을 공유(share the loss)'하는 방식으로 보험을 제시하였다 (IPCC, 2001). 기후변화 적응에 있어서 보험이 중요한 역할을 할 수 있을 것이라는 인식에 바탕을 두고 Germanwatch, Munich Re, 스위스연방기술원(Swiss Federal institute of Technology), Tyndall Centre, Potsdam Institute for Climate Impact Research, 세계은행 등에 의해 2005 년에 Munich Climate Insurance Initiative가 설립되었으며 이것의 목적은 공공과 민간부분의 전 문성과 자원을 결합하여 보험과 관련된 해결책을 개발하고 이것의 활용을 위해 파일롯 프로젝트 를 수행하며 다른 기관들과의 협력을 추구하고 손실을 감소시킬 수 있는 방안을 발굴하는 것이다. Munich Climate Insurance Initiative는 제11차 기후변화협약 당사국총회에서 기후 보험에 대한 행사를 주최하는 등 활발한 활동을 펼치고 있다.

\section{〈표 4〉기후변화협약의 제4조8항}

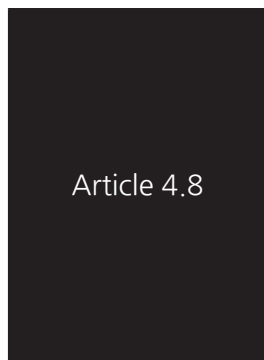

기후변화의 악영향에 민감한 개도국의 시급한 상황을 고려해 그들의 특수한 상황을 만족 시키기 위한 조치들(재정지원, 보험, 기술이전)에 대한 충분한 고려

The parties shall give full consideration to what actions are necessary under the Convention, including actions related to funding, insurance and the transfer of technology, to meet the specific needs and concerns of developing country Parties arising from the adverse effects of climate change and/or the impact of the implementation of response measures.

전통적인 또는 일반적인 의미의 보험은 계약에 의해 다수의 가입자로부터 작은 금액을 모아서 소수 가 갖게 될 손실의 부담을 서로 나누어 갖는 것으로 개인이나 기업들은 보험을 통해 재난 발생 이 후의 어려운 시기를 넘길 수 있으며 작물을 다시 심고 사업을 재건할 수 있다. 정부입장에서 보험 은 재건 비용 및 이와 관련한 재정적자의 이자 비용을 줄일 수 있게 해준다. 이러한 장점에도 불구 하고 보험 분야에서 날씨와 관련된 보험은 항상 쉽지 않은 영역이었다. 기상재난은 종종 연관된 위 험(correlated risk)으로 간주된다. 즉 특정 지역에 거주하는 많은 사람들이 하나의 사건에 영향을 받고 그 결과로 그들 모두가 손실을 입는다. 이러한 대규모의 기상이변은 보험회사의 포트폴리오에 심각한 영향을 미친다. 기후보험은 기후재난을 겪을 위험이 높은 사람들만 보험에 가입 ${ }^{11)}$ 하기에 손

11) 이를 adverse selection이라 함 
실이 클 가능성이 높고, 손실을 측정하기 위한 객관적인 지표가 부족하며 특히 적정한 가격의 재보 험 시장(reinsurance markets)이 존재하지 않을 경우 정부는 재난처리비용을 채권발행 등을 통한 차입이나 세금의 인상에 의존하게 된다. 기후변화 위험에 더 많이 노출된 개도국에서는 공여기관의 지원이 없다면 이러한 비용을 감당할 수가 없다.

기후 관련 보험시장은 보험회사와 가입자 모두 위험에 대한 이해의 부족과 정보부족으로 활성화되 지 못하였다. 고소득 국가의 재난 관련 보험의 가입률은 $30 \%$ 에 이르지만 독일과 같은 선진국에서 도 최근의 극심한 홍수로 인한 범람의 피해자들 중 단 $3 \%$ 만이 보험에 가입되어 있었으며 나머지 비 용은 독일 정부가 해결하여야했다. 개도국의 경우는 상황이 더 좋지 않다. 중소득국에서는 $3 \%$, 저 소득국에서는 가구와 기업의 $1 \%$ 만이 이러한 보험에 가입되어 있다(Munich Re, 2005). 보험사들 은 또한 과거의 기후 데이터가 미래의 위험을 알려주는데 성공적인 지표가 되지 못하는 것을 발견 하였으며 이는 변덕스러운 시장상황과 보험료의 증가를 가져왔다. 예로 허리케인 앤드류(Andrew) 와 같은 고비용을 발생시키는 사건은 전 세계적으로 영향을 미치며 하룻밤사이에 고위험 국가들의 보험료를 두 배로 증가시켰다.

낮은 가입률을 해결하기 위해선 개도국 주민들이 가입할 수 있는 수준으로 보험료가 산정될 수 있 는 방안을 개발하는 것이 필요하다. 세계은행은 개도국이 대규모의 재난에 대비할 수 있도록 맞춤 형 자금 전략의 개발을 도와주었으며 빈농이 사기업이 제공하는 가뭄 보험의 비용을 지불할 수 있 도록 기부자를 모집하기도 하였다.

기후변화와 관련하여 몇몇 선진개발원조 기관들은 도덕적 해이 ${ }^{12)}$, 비대칭적 정보 ${ }^{13)}$ 등의 단점을 가 지고 있는 전통적인 작물 보험을 벗어나 새로운 시도를 하고 있다. 최근 논의되고 있는 보험은 지수 보험(index insurance)으로 보험가입자 개개인의 피해규모에 기초하여 보험금을 산정하는 전통적 인 보험과는 달리 손실규모를 대신할 수 있는 지수(index)를 사용하여 보험지급액을 산정한다. 지 수는 관심을 가지고 있는 변수(예를 들면 농작물의 생산량)와 밀접한 연관관계가 존재하는 객관적 인 측정값(예: 강우량, 풍속, 기온 등)에 기초한다. 지수보험은 미리 정해진 역치(threshold)가 있 는데 이 값을 넘어서면서부터 보험금이 지급되기 시작한다. 보험금의 지급은 지수값이 한계값(limit value)에 접근할수록 증가하다가 한계값 이후에는 동일한 보험금이 지급된다. 인도 정부는 세계은 행의 지원으로 날씨에 기초한 작물보험을 설립하였고 이것은 현재 60 만명 이상의 농부들이 가뭄에 대항하도록 보호하고 있다.

12) Moral hazard : 보험금이 지급될 것이라는 것을 인식하고 위험을 증가시키는 방법으로 가입자들이 행동하는 것을 일컬음

13) Asymmetric information : 보험회사와 가입자가 손실의 규모 등에 대해 서로 다른 정보를 가지고 있는 것을 말함. 이러한 의견 차가 클수록 조사 수행 등을 위한 행정경비가 증가 
지수보험의 장점은 계산하는데 시간이 많이 소요되는 재난피해액이 아닌 강우량과 같은 데이터 에 바탕을 두고 보험금 지급이 계산되기에 필요한 정보가 간단하다는 것과 도덕적 해이와 역선택 (adverse selection)이 감소하고 적은 행정경비가 필요하다는 것이다. 이러한 장점을 살려서 개도 국에서 $\mathrm{PPP}$ 를 통한 기후보험의 활성화를 달성하기 위해 정부 또는 공여기관이 법률 환경 등을 정 비하고 데이터 수집과 활용 시스템을 향상시키며 기후변화 보험의 사용에 대한 교육을 실시하고 세 계 시장에의 접근성을 높일 수 있도록 지원하는 것이 필요하다. 또한 개도국의 보험회사들은 커다 란 기후재난 후에 동반되는 대규모의 손실을 감당할 정도로 재정적으로 튼튼하지 못하다. 따라서 위험을 감당할 수 있도록 외부 자금원에 접근할 수 있는 방안을 개발하여야한다. 개도국 정부가 가 입힐 수 있는 것들로는 전통적인 보험, 국제금융시장에서의 재보험, 다른 취약국가들과 함께하는 그룹보험, 국가자금에 바탕을 둔 self-insurance 등이 있다. 그리고 공여기관들은 개도국의 정부 에게 시장을 왜곡하지 않고 장기적인 보험시장의 성장을 위한 정보 등을 제공하여야한다. 지역 및 국가 수준에서 민관의 역할 관계와 전지구적 협력관계를 〈그림 6〉에 묘사하였다.

\section{〈그림 6〉 기후 보험 프로그램에 대한 개략도}

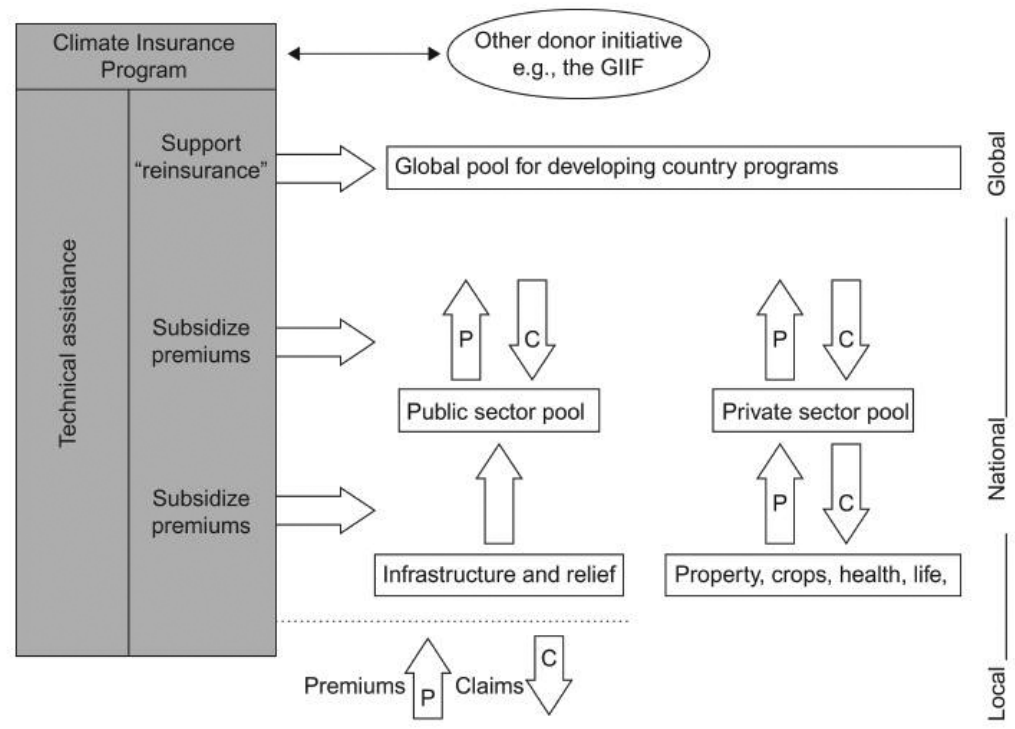

출처: Linnerooth-Bayer and Mechler, 2006

기후변화적응과 관련한 보험의 사례로는 The Commonwealth Disaster Management Agency (CDMA)하에 2002년에 설립된 The Commonwealth and Smaller States Disaster Management Scheme이 있다. 이것은 보험료의 수준을 납입 가능한 범위 내에서 제공하기 위해 디자인되었으며 따라서 정부의 융자잔고(outstanding loans)가 재난 발생 후 최장 3년까지는 지속 적으로 사용될 수 있도록 함을 목적으로 하였다. 모든 지방정부들은 그들의 취약도와 상관없이 보 
험가입된 총액의 $1 \%$ 를 보험료로 지불하며 보험금의 지급은 독립적으로 얻어진 기상 데이타에 기초 하여 100 분의 1 확률로 발생하는 극단적인 기후재난에 의해 촉발된다. 이 시스템은 CDMA Ltd와 민간보험업자인 Marsh \& McLennan에 의해 개발되었으며 위험에 취약한 중앙아메리카의 국가들 이 최초의 가입자가 될 것으로 기대되어지고 있다.

또 다른 대표적인 사례는 멕시코에서 세계은행의 기술적 지원으로 1996년에 설립된 the Fund for Natural Disasters(FONDEN)이다. 국민들의 세금에 의해 설립된 이 기금의 목적은 민간보험에 가 입할 수 없는 빈농과 도시빈민을 지원하기 위한 것으로 재해연계채권 ${ }^{14}$ 과 같은 방식을 사용하여 허 리케인과 같은 거대 재해에 대한 위험을 자본시장으로 전가, 손실 규모를 축소하였다. 그리하여 멕 시코는 2006년 최초의 재해연계채권을 발행한 국가가 되었다(DFID, 2004).

\section{V. 결론}

올해 말 코펜하겐에서 열리는 기후변화협약 당사국 총회(COP15)에서는 새로운 기후체제(Post2012)에 대한 논의와 함께 개도국의 기후변화 대응 지원을 위한 선진국들의 재정지원(financing) 에 대한 논의도 이루어질 것으로 보인다. 그러나 개발도상국의 기후변화 대응을 위한 막대한 비용 을, 그것도 기존 $\mathrm{ODA}$ 지원 외에 추가적인 재원으로 충당한다는 것은 쉽지 않아 보인다. 그러므로 앞으로도 국제사회는 기후변화대응을 위해 민간부문의 재정적, 기술적 역량을 더욱 절실히 필요로 하게 될 것이다.

민관협력은 기본적으로 공공부문의 일방적인 요구에 의해서만 형성될 수는 없으므로 민간부문의 참여를 촉진시킬 수 있는 충분한 유인책의 마련이 시급하다. 완화 측면에서는 탄소배출 가격에 적 절한 사회적 비용을 부담시키고 탄소시장의 예측가능성을 확보하는 것이 급선무다. 그리고 국제기 구들은 공공금융을 활용하여 탄소펀드를 확대 조성함으로써 민간기업들이 투자에 대한 리스크를 줄일 수 있도록 협조해야 한다. 아울러 청정에너지 기술의 연구개발과 보급이 가속화될 수 있도록 보조금 지원 등 충분한 인센티브를 부여하고 화석연료에 대한 기존 보조금 제도는 폐지해야 한다. 적응 측면에서는 전통적인 물 분야에서 '전략적 재원 계획' 등을 통해 민관협력의 효율성을 지속적 으로 강화해야 할 것이며, 기후변화로 인한 손실을 분산시킬 수 있는 기후보험 시장의 활성화를 위 해 혁신적인 보험상품의 개발, 정보수집 및 활용 시스템 구축 그리고 외부 금융시장과의 접근성 향

14) Cat bond라고 불리우며 이는 catastrophe bond의 준말로 자연재해 관련 보험상품을 판매한 보험사가 채권을 발행해 자 본시장에 유통시킴으로써 자본시장의 투자자들에게 그 위험을 전가하는 새로운 형태의 위험 관리 기법임. 
상 등을 지원해야 한다.

마지막으로 이러한 조치들이 단순히 기후변화에 대한 대응을 넘어서 개도국의 경제 - 사회개발에도 기여하도록 하기 위해서는 $\mathrm{ODA}$ 의 역할이 긴요하다. 예를 들어 $\mathrm{ODA}$ 는 중국, 인도 등 아시아 신흥 국가에 집중된 민간투자를 아프리카 등 최빈국으로 확대될 수 있도록 유도하고 개도국 내 탄소시장 이 안정적으로 형성될 수 있도록 법제도 구축을 지원하는데 기여할 수 있다. 아울러 민간기업의 “빈 곤감소에 기여하는 (pro-poor)' 기후보험의 개발을 지원하거나 기후보험의 사용을 위한 교육을 실 시할 수 있으며 세계시장에의 접근성을 높일 수 있도록 지원할 수 있다. 이와 같이 공공부문이 적합 한 정책과 금융을 활용해 민간부문의 참여를 촉진하고, 민관협력의 틀 속에서 MDGs 달성에도 기 여할 수 있도록 유도해가는 ODA의 역할이 요구된다. 


\section{참고문헌}

\section{1. 국내문헌}

박형건. 2007. 「배출권 거래제도 시행에 따른 탄소펀드 현황」.『산은조사월보』 2007년 통권 616호: 79 95면. 서울.

박희수, 임소영. 2009. 「기후변화 관련 최근 원조 현황과 논의 방향: 물 분야」.

『국제개발협력』 2009년 통권 2호: 65 84면. 성남:한국국제협력단.

유엔글로벌컴팩트 한국협회. 2009.「기업의 기후변화 대응과 녹색성장」.『유엔 글로벌콤팩트 한국협회 심포지엄 자료』.서울:유엔글로벌컴팩트 한국협회

한국수출입은행. 2009.『해외 $\mathrm{CDM}$ 사업 전문 가이드』. 서울:한국수출입은행

\section{2. 국외문헌}

ADB. 2006. Carbon Market Initiative: The Asia Pacific Carbon Fund, Manila: Asian Development Bank.

ADB. 2007. Clean Energy Financing Partnership Facility: Establishment of the Clean Energy Fund and Clean Energy Trust Funds, Manila: Asian Development Bank.

Anna Pegels. 2008. Financing for Development Series: Leveraging Private Investment in Climate Change Mitigation. Bonn: German Development Institute

Carbon Finance Unit. 2009. Annual Report 2008: Carbon Finance for Sustainable Development, Washington, DC: World Bank.

Climate Group. 2007. Public-Private Partnerships: Local Initiatives 2007, London: The Climate Group.

DFID. 2004. Key Sheets on Climate Change and Poverty, available at http://www.dfid.gov. uk/Documents/publications/climatechange/8insurance.pdf

IBRD. 2007. Catalyzing Private Investment for a Low-Carbon Economy: World Bank Group Progress on Renewable Energy and Energy Efficiency in Fiscal 2007, Washington, DC: World Bank Group.

IEA. 2008. Key World Energy Statistics 2008, Paris: International Energy Agency. 
IPCC. 2001. Climate Change 2001: Impacts, Adaptation and Vulnerability, Contribution of Working Group II to the Third Assessment Report of the Intergovernmental Panel on Climate Change. Cambridge: Cambridge University Press.

Linnerooth-Bayer, J. and Mechler, R. 2006. "Insurance for assisting adaptation to climate change in developing countries: a proposed strategy.” Climate Policy. 6(6). 621-636.

Mathys, A. 2006. "Water and Sanitation in Africa: Experience of a Private Operator," presented at OECD-Water and Sanitation in Africa, December 2006, Paris

Moore, D. 2006. "Developing Sustainable Financing for Water Supply and Sanitation: Philippine Water Revolving Fund", presented at the 4th World Water Congress, 14 September 2006, Beijing, China

Munnich Re. 2005. Natural Disasters According to Country Income Groups 1980-2004. Munich, Germany: Munich Re NatCatSERVICE.

OECD. 2003. Policy Brief: Public-Private Partnerships in the Urban Water Sector. Paris: OECD Publishing.

OECD. 2009a. Development Cooperation Report 2009. OECD Journal on Development. Volume 10/1. Paris: OECD Publishing

OECD. 2009b. Private Sector Participation in Water Infrastructure: OECD Checklist for Public Actinon. Paris: OECD Publishing.

OECD. 2009c. Managing Water for All: An OECD Perspective on Pricing and Financing. Paris: OECD Publishing.

Stern, Nicholas. 2006. Economics of Climate Change: the Stern Review, Cambridge: Cambridge University Press.

UNDP. 2007, Human Development Report 2007/2008: Fighting Climate Change: Human Solidarity in a divided world. New York: UNDP

World Bank. 2004. Renewable Energy for Development, Washington, DC: World Bank Group. 
World Bank Independent Evaluation Group. 2006. New Renewable Energy - A Review of the World Bank's Assistance, Washington, DC: World Bank Group.

Zechter, R.H. 2009. "Carbon Finance at the World Bank." presented at the Green Business Forum 2009, 16 July 2009, Seoul.

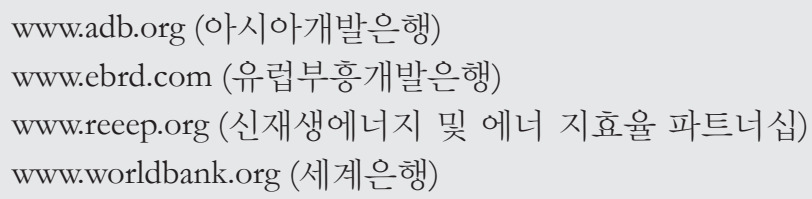

